\title{
Apparent Mineralocorticoid Excess Syndrome in a Brazilian Boy Caused by the Homozygous Missense Mutation p.R186C in the HSD11B2 Gene
}

\begin{abstract}
The apparent mineralocorticoid excess syndrome (AME) is a rare autosomal recessive disorder due to the deficiency of 11/-hydroxysteroid dehydrogenase type 2 enzyme (11beta-HSD2). The 11beta-HSD2 enzyme, encoded by HSD11B2 gene, metabolizes active cortisol in cortisone. Mutations on HSD11B2 gene affect the enzyme activity by leading to an excess of cortisol, which causes its inappropriate access to mineralocorticoid receptor. Therefore, cortisol will bind mineralocorticoid receptor. The human HSD11B2 gene maps to chromosome 16q22 and consists of five exons encoding a protein of 405 amino acids. We present here clinical and molecular studies on a Brazilian boy who was born pre-term after an oligodramnious pregnancy. He was diagnosed as having AME at the age of 26 months. His parents are second cousins. Molecular characterization of the HSD11B2 gene revealed the homozygous mutation p.R186C. The patient described here is the second case of HDS11B2 gene mutation reported in Brazilian patients with AME. (Arq Bras Endocrinol Metab 2008; 52/8:1277-1281)
\end{abstract}

Keywords: Apparent mineralocorticoid excess; HSD11B2 gene; Hypertension; Deficiency of 11 $\beta$-hydroxysteroid dehydrogenase type 2; Mutations

\section{RESUMO}

Síndrome de Excesso Aparente de Mineralocorticóide em um Menino Brasileiro Causada pela Mutação p.R186C em Homozigose no Gene HSD11B2.

A síndrome de excesso aparente de mineralocorticóide (AME) é uma doença autossômica recessiva rara devido à deficiência da enzima 11 $\beta$-hidroxiesteróide desidrogenase tipo 2 (11beta-HSD2). A enzima 11beta-HSD2 metaboliza o cortisol ativo a cortisona. As mutações no gene HSD11B2, que codifica a enzima, afetam sua atividade levando a um excesso de cortisol, que terá acesso inapropriado ao receptor de mineralocorticóide, competindo com a ligação da aldosterona. O gene HDS11B2 humano está localizado no cromossomo $16 q 22$ e é formado por 5 éxons que codificam uma proteína de 405 aminoácidos. Este relato apresenta os estudos clínicos e moleculares de um paciente brasileiro do sexo masculino que nasceu prematuro depois de uma gestação sob oligodrâmnio. Recebeu o diagnóstico de AME com 26 meses de idade. Seus pais são primos em segundo grau. A caracterização molecular do gene HSD11B2 revelou a mutação p.R186C em homozigose. O paciente descrito é o segundo caso relatado de brasileiro com mutação no gene HSD11B2. (Arq Bras Endocrinol Metab 2008; 52/8:1277-1281)

Descritores: Excesso aparente de mineralocorticóide; Gene HDS11B2; Hipertensão; Deficiência da11ß-hidroxiesteróide desidrogenase tipo 2; Mutações

\section{INTRODUCTION}

pparent mineralocorticoid excess (AME; OMIM \# 207765) is a rare autosomal recessive disorder, which consists in an inherited form of hyperten- clinical case report

\author{
* Fernanda Borchers CoelI \\ * * LÚCIO FábIo CaLdas FerRaz \\ SOFIA H. V. DE LEMOS-MARINI \\ Sumara Zuanazi Pinto RigatTo \\ Vera Maria Santoro Belangero \\ Maricilda Palandi de-Mello
}

Laboratório de Genética

Molecular Humana, Centro de

Biologia Molecular e Engenharia

Genética, Universidade Estadual

de Campinas (FBC, LFCF, MPM);

Centro de Investigação em

Pediatria, Faculdade de

Ciências Médicas,

Departamento de Pediatria,

Universidade Estadual de

Campinas (SHVLM, SZPR, VMSB),

Campinas, SP, Brasil.

** Share first authorship

Received in 25/8/2008

Accepetd in 14/10/2008 
sion caused by the deficiency of $11 \beta$-hydroxysteroid dehydrogenase type 2 (1lbeta-HSD2) (1-3). This enzyme is highly expressed in mineralocorticoid target tissues and functions unidirectionally to convert cortisol to cortisone, an inactive form (4). Although cortisol is a less potent mineralocorticoid than aldosterone, the main mineralocorticoid produced in the adrenal gland, both aldosterone and cortisol bind to the mineralocorticoid receptor (MR) with equal affinity (5), whereas cortisone does not. Therefore, 1 lbeta-HSD2 enzyme protects normal subjects from cortisol intoxication by converting it into cortisone and providing a mechanism that ensures the proper occupation of MR by aldosterone (6). As cortisol is secreted in concentrations much higher than aldosterone, the deficiency of llbetaHSD2 leads to an inappropriate inactivation of cortisol, which in excess, acts as a mineralocorticoid. This cortisol excess stimulates the MR causing intense sodium retention, hypokalemia and hypertension (1-3).

Two isoforms of 11 beta-HSD have been identified and characterized (7). The type 1 isoform, which is expressed in several human tissues, is a NADP-dependent enzyme with reductase activity $(8,9)$. The type 2 isoform, which is only $20-26 \%$ identical to type 1 , is NADdependent and presents dehydrogenase activity (10). The human HSDIIB2 gene, encoding the 11betaHSD2 enzyme, is located on chromosome 16q22, consists of 5 exons spanning about $6.2 \mathrm{~Kb}$, and encodes a protein of 405 amino acids (11).

AME is a result of mutations in HSD11B2 gene (12-15). In general, the disease is present in early childhood, with a severe phenotype including low birth weight, failure to thrive, hypokalemic metabolic alkalosis, and high mortality rate in untreated patients (2, 16). However, milder phenotypes have been described in adults with clinical features such as hypertension without electrolyte abnormalities (17-20). Milder phenotypes are associated with mutations causing only partial inactivation of HSD11B2 (21).

In this study, we report a boy with typical clinical features of AME with p.R186C homozygous mutation in the HSDIIB2 gene.

\section{SUBJECTS AND METHODS}

Blood specimens and clinical data of the patient and relatives were collected with approval by the appropriate institutional review board; signed informed consent was obtained.

\section{Clinical data}

A Brazilian male, son of a consanguineous marriage, was born pre-term (weight $=1,700 \mathrm{~g}$; length $=40$ $\mathrm{cm})$, Apgar score 8-9, after an oligodramnious pregnancy. He had normal male genitalia with palpable testes. His development was normal up to the age of 5 months when he had bronchiolitis. Thereafter he presented failure to thrive. When he was 17 months old he was admitted in a hospital for pneumonia when he presented polyuria, polydipsia, hypokalemia (serum potassium, $1.9 \mathrm{mmol} / \mathrm{L}$ ) and hypertension. He was first examined by us at the age of 26 months when he was referred to our hospital for evaluation because prednisone and chlorthalidone failed to control his labile hypertension. At this time his weigh $(8,580 \mathrm{~g})$ and height $(76.8 \mathrm{~cm})$ were both below the third percentile $(\mathrm{zW}=-3.32$ and $\mathrm{zH}=-2.53)$. He also presented hypertension $(130 / 90 \mathrm{mmHg})$. Laboratorial findings indicated hypokalemia (serum potassium, $2.5 \mathrm{mmol} / \mathrm{L})$, alkalosis $(\mathrm{pH}=7.5 \mathrm{l})$ and normal sodium $(141 \mathrm{mmol} / \mathrm{L})$, plasma renin activity $(0.48$ $\mathrm{ng} / \mathrm{ml} / \mathrm{h}$, normal 0.15 to 2.33 ), aldosterone $(26 \mathrm{pg} /$ $\mathrm{ml}$, normal 10 to $160 \mathrm{pg} / \mathrm{mL})$, ll-deoxycortisol $(2.0$ $\mathrm{ng} / \mathrm{mL}$, normal $<8.0 \mathrm{ng} / \mathrm{mL}$ ) and serum cortisol $(9.9 \mu \mathrm{g} / \mathrm{dL}$, normal 7.58 to $27 \mu \mathrm{g} / \mathrm{dL}$,$) . On 24$-hour urine he presented normal cortisol $(31.9 \mu \mathrm{g} / 24 \mathrm{hs}$, normal 20 to $90 \mu \mathrm{g} / 24 \mathrm{hs}$ ) and hypercalciuria (18 $\mathrm{mg} / \mathrm{kg} /$ day, normal $<4 \mathrm{mg} / \mathrm{kg} /$ day). Unfortunately, neither cortisol nor cortisone urinary metabolites could be evaluated.

Renal ultrasounds revealed the presence of bilateral nephrocalcinosis (not progressive) whereas cardiac echocardiography showed mild left ventricular hypertrophy when he was 5 years old.

He has been treated with diuretics, antihypertensive drugs, salt restriction and potassium supplementation and he responded well to the treatment. On follow-up, biochemical results indicated normal serum levels of both sodium and potassium, and blood pressure in the upper limit of normality. He also had an improvement of growth parameters. At the age of 11.1 years his weight was $32,300 \mathrm{~g}(\mathrm{Z}=-0.6 \mathrm{l})$, height $140.4 \mathrm{~cm}(\mathrm{Z}=-0.48)$, pubertal stage G2P3, his blood pressure was normal $(110 / 60 \mathrm{mmHg})$. In the last consultation, his clinical features were stable upon treatment with $\mathrm{KCl}$ (3.30 g/day), Amiloride (12.5 mg/ day), Captopril (100 mg/day), Hydrochlorothiazide $(25 \mathrm{mg} /$ day $)$, Atenolol (18 mg/day) and Losartam Potassium $(25 \mathrm{mg} /$ day $)$. 


\section{Molecular analysis}

Genomic DNA was extracted from peripheral blood leukocytes by standard phenol/chloroform method (22). HSDIIB2 gene was amplified by PCR amplification of the entire coding region including exon-intron junctions and both 5'UTR and 3'UTR regions using synthetic oligonucleotides (Invitrogen, CA, USA) as primers (table 1 ), which were designed using Primer 3 open access software (http://primer3.sourceforge. net). The amplified fragments were directly sequenced using Big Dye TM Terminator Cycle Sequencing Kit V3.1 Ready Reaction (ABI PRISM / PE Biosystems, Foster City, CA, USA). The sequences obtained in an ABI377 Semi-Automated Sequencer (ABI PRISM / PE Biosystems) were compared to the normal sequence of the gene (NCBI \# U27317).

\section{RESULT}

HSD11B2 sequence analysis on patient's DNA revealed a c. $556 \mathrm{C}>\mathrm{T}$ homozygous transition in codon 186 located in exon 3 . This nucleotide substitution leads to the p.R186C missense mutation (Figure 1A). Further sequence analysis on parent's DNA samples showed heterozygosis for the mutation in both father and mother (Figure 1B).

\section{DISCUSSION}

In the present study we describe a boy diagnosed as having AME disease. Clinical and hormonal data supported the presence of a deficiency in the 11 beta-HSD2 enzyme activity. Facing clinical and laboratorial featu-

Table 1. Primers used for PCR HSD1 1B2 gene amplification.

\begin{tabular}{|c|c|c|c|c|}
\hline & Primers & Sequences $\left(5^{-}--3^{\prime}\right)$ & $\operatorname{Tm}\left({ }^{\circ} \mathrm{C}\right)$ & Size $(p b)$ \\
\hline \multirow{2}{*}{$5^{\circ}$-UTR } & $\mathrm{HSD} 11 \mathrm{~B} 2-5^{\circ}-\mathrm{F}$ & GGGGCTCTTCATAAGCTCG & \multirow{2}{*}{60} & \multirow{2}{*}{255} \\
\hline & HSD $11 \mathrm{~B} 2-5^{-}-\mathrm{R}$ & CCAGACGCAGGTCTGAGC & & \\
\hline \multirow{2}{*}{ Exon 1} & HSD11B2-1F & TAGAAGCTCTCTCTCCCCGC & \multirow{2}{*}{61} & \multirow{2}{*}{398} \\
\hline & HSD11B2-1R & CCTGTTGAGTGTCCAGTCCC & & \\
\hline \multirow{2}{*}{ Exon 2} & HSD1 1B2-2F & TGGTGATTCTGGGGTTGTCT & \multirow{2}{*}{60} & \multirow{2}{*}{394} \\
\hline & HSD $11 \mathrm{~B} 2-2 \mathrm{R}$ & CACAGAGCAGAGGAGGGAAG & & \\
\hline \multirow{2}{*}{ Exon 3} & HSD11B2-3F & GACACGGGGACTGGAAGTT & \multirow{2}{*}{60} & \multirow{2}{*}{288} \\
\hline & HSD $11 B 2-3 R$ & GGCTCCITTTTGCTCCAGT & & \\
\hline \multirow{2}{*}{ Exon 4} & HSD1 1B2-4F & ACTGGAGCAAAAAGGAGCC & \multirow{2}{*}{60} & \multirow{2}{*}{295} \\
\hline & HSD $11 \mathrm{~B} 2-4 \mathrm{R}$ & СTGСССССАТАAGACСАTT & & \\
\hline \multirow{2}{*}{ Exon 51} & HSD $11 \mathrm{~B} 2-5 \mathrm{IF}$ & CGCGGGTTAAACAGTCCTAA & \multirow{2}{*}{61} & \multirow{2}{*}{300} \\
\hline & HSD $11 \mathrm{~B} 2-5 \mathrm{IR}$ & CCCTGGCCGGGGTAATAG & & \\
\hline \multirow{2}{*}{ Exon 5II } & HSD $11 \mathrm{~B} 2-5 \mathrm{IIF}$ & ATGCCATCACAGATGCGCT & \multirow{2}{*}{62} & \multirow{2}{*}{292} \\
\hline & HSD $11 \mathrm{~B} 2-5 \mathrm{IIR}$ & GCCTCCTGTGCTGCAGTG & & \\
\hline \multirow{2}{*}{$3-$ UTR - I } & HSD 11 B2-3־-IF & AGGACCCAAACCTGAGCC & \multirow{2}{*}{60} & \multirow{2}{*}{310} \\
\hline & HSD $11 \mathrm{~B} 2-3^{-}-\mathrm{IR}$ & GTTCTCCAAGCTGCAGGGTA & & \\
\hline \multirow{2}{*}{$3^{-}-U T R-11$} & HSD11B2-3־-IIF & CACTGITTCATGAGCCCAAA & \multirow{2}{*}{60} & \multirow{2}{*}{405} \\
\hline & HSD $11 \mathrm{~B} 2-3^{-}-\mathrm{IIR}$ & CACACTGTGTCACTCAGCCA & & \\
\hline
\end{tabular}


A

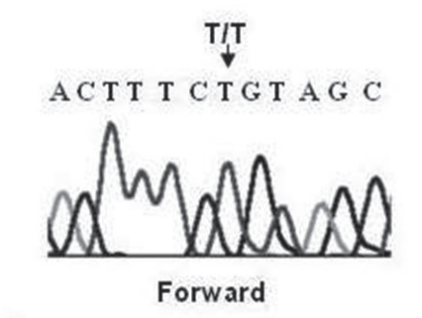

B
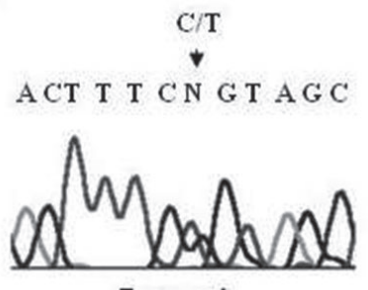

Forward
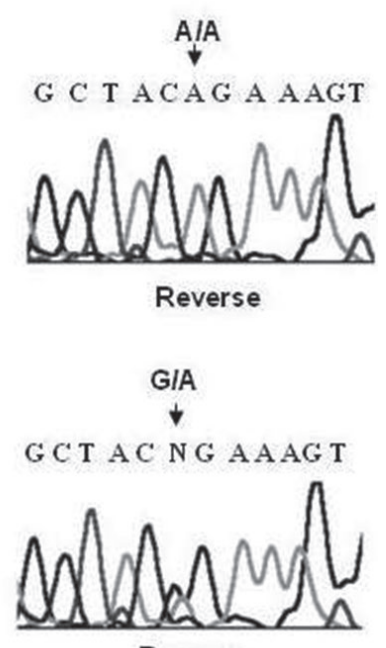

Reverse

Figure 1. HSD11B2 gene sequencing electropherograms showing part of exon 3. The $\underline{C} G T>$ IGT nucleotide change is denoted. This change causes the missense mutation R186C observed in homozygosis for patient's DNA (A) in the sequencing with both forward and reverse primers. The heterozygous status was verified for his parents (B).

res, the etiologies raised were: AME and Liddle Syndrome. Several clinical characteristics, such as low birth weight, failure to thrive, hypercalciuria and also parent's consanguinity favored AME diagnosis and led us to search for HSD11B2 gene mutations.

Molecular investigation identified the p.R186C homozygous mutation in the HSDIIB2 gene. This mutation was previously described by Wilson and cols. (23). The aminoacid residue Rl86 is conserved across several species. In addition, computer analysis of the predicted protein structure revealed that $\mathrm{p} . \mathrm{R} 186 \mathrm{C}$ substitution yields a protein with a new P-sheet from residues 189 to 195 and an increased hydrophobicity from residues 180 to 191 (24). In vitro enzymatic activity assays showed complete inactivation of 11 beta-HSD2 enzyme due to p.R186C mutation (24).

To date, over 30 different mutations on HSDIIB2 gene have been reported worldwide and in many ethnic groups, including Caucasians, Africans, Asians, and American Indians (25-28). Consanguinity, endogamy or a founder effect for AME have been considered in several families, especially those from ethnics in whom recurrence of certain HSD11B2 mutations is observed (25). The Brazilian family described here is formed by a consanguineous marriage and both father and mother

are p.R186C carriers. Since this mutation was previously described segregating in an African-American family (20), a founder effect should be considered. However, in the present case it is difficult to explain the mutation recurrence by considering a founder effect of an African-derived disease-causing allele without analyzing molecular markers, which could give an estimative of African ancestry index for this family as defined by Parra and cols. (29). Therefore, we cannot discard the possibility of this mutated allele being an Africanoriginated allele.

Conversely, the $\mathrm{C}>\mathrm{T}$ transition at codon 186 $(\underline{\mathbf{C G T}}>\underline{\mathbf{T}} \mathrm{GT})$ is a typical $\mathrm{CpG}$-consequence mutation. This dinucleotide is considered to be prompt to undergo mutations through spontaneous deamination of cytidine to uracil $(30,31)$. Therefore, the occurrence of the p.Rl86C mutation in two unrelated families could suggest that the codon R186 is a hot spot for mutations in HSDIIB2 gene, like other mutations located in exons 3 to $5(21,32)$. However, the number of patients bearing the mutation is low, therefore there are no significant evidences for this possibility unless more patients are studied.

In general there are few cases of AME reported worldwide, since this is a very rare autosomal recessive disorder $(25,27)$. The boy described in the present paper was clinically diagnosed with AME and molecular findings confirmed the phenotype. This is the second case of AME with a deleterious HDS11B2 gene mutation reported in Brazilian patients (33).

Acknowledgements: We thank Maria M. Vasconcelos Rosa for assistance and technical support. We thank Conselho Nacional de Desenvolvimento Científico e Tecnológico (CNPq) and Coordenação de Aperfeiçoamento de Pessoal de Nível Superior (CAPES) for financial support. The authors would also like to thank the family studied for agreeing to participate in this research.

\section{REFERENCES}

1. White PC, Mune T, Agarwal AK. 11beta-Hydroxysteroid dehydrogenase and the syndrome of apparent mineralocorticoid excess. Endocr Rev. 1997;18(1):135-56.

2. New MI, Wilson RC. Steroid disorders in children: congenital adrenal hyperplasia and apparent mineralocorticoid excess. Proc Natl Acad Sci USA. 1999;96(22):12790-7.

3. Luft FC. Mendelian forms of human hypertension and mechanisms of disease. Clin Med Res. 2003;1(4):291-300.

4. Krozowski Z. The 11beta-hydroxysteroid dehydrogenases: functions and physiological effects. Mol Cell Endocrinol 1999; 151(1-2): 121-7. 
5. Krozowski ZS, Funder JW. Renal mineralocorticoid receptors and hippocampal corticosterone-binding species have identical intrinsic steroid specificity. Proc Natl Acad Sci USA. 1983;80(19): 6056-60.

6. Edwards C, Stewart P, Burt D, Brett L, Mclntyre M, Sutanto W, et al. Localisation of 11b-hydroxysteroid dehydrogenase: tissue specific protector of the mineralocorticoid receptor. Lancet. 1988;2(8618):986-9.

7. Krozowski ZS, Provencher PH, Smith RE, Obeyesekere VR, Mercer WR, Albiston AL. Isozymes of 11 beta-hydroxysteroid dehydrogenase: which enzyme endows mineralocorticoid specificity? Steroids. 1994;59(2):116-20.

8. Moore CC, Mellon SH, Murai J, Siiteri PK, Miller WL. Structure and function of the hepatic form of 11b-hydroxysteroid dehydrogenase in the squirrel monkey, an animal model of glucocorticoid resistance. Endocrinology. 1993;133(1): 368-75.

9. Stewart PM, Murry BA, Mason Jl. Human kidney $11 \beta$-hydroxysteroid dehydrogenase is a high affinity nicotinamide adenine dinucleotide-dependent enzyme and differs from the cloned type I isoform. J Clin Endocrinol Metab. 1994;79(2):480-4.

10. Rusvai E, Naray-Fejes-Toth A. A new isoform of 11 b-hydroxysteroid dehydrogenase in aldosterone target cells. J Biol Chem. 1993;268(15):10717-20.

11. Agarwal AK, Rogerson FM, Mune T, White PC. Gene structure and chromosomal localization of the human HSD11K gene encoding the kidney (type 2) isozyme of 11 beta-hydroxysteroid dehydrogenase. Genomics. 1995;29(1):195-9.

12. Mune T, Rogerson FM, Nikkilä H, Agarwal AK, White PC. Human hypertension caused by mutations in the kidney isozyme of 11beta-hydroxysteroid dehydrogenase. Nat Genet. 1995;10(4):394-9.

13. Li A, Tedde R, Krozowski ZS, Pala A, Li KX, Shackleton $\mathrm{CH}$, et al. Molecular basis for hypertension in the "type II variant" of apparent mineralocorticoid excess. Am J Hum Genet. 1998;63(2):370-9.

14. New MI, Geller DS, Fallo F, Wilson RC. Monogenic low renin hypertension. Trends Endocrinol Metab. 2005;16(3):92-7.

15. Stewart PM, Krozowski ZS, Gupta A, Milford DV, Howie AJ, Sheppard MC, Whorwood CB. Hypertension in the syndrome of apparent mineralocorticoid excess due to mutation of the 11 beta-hydroxysteroid dehydrogenase type 2 gene. Lancet. 1996;347(8994):88-91.

16. Dave-Sharma S, Wilson RC, Harbison MD, Newfield R, Azar MR, Krozowski ZS, et al. Examination of genotype and phenotype relationships in 14 patients with apparent mineralocorticoid excess. J Clin Endocrin Metab. 1998;83(7):2244-54.

17. Ugrasbul F, Wiens T, Rubinstein P, New MI, Wilson RC. Prevalence of mild apparent mineralocorticoid excess in Mennonites. J Clin Endocrinol Metab. 1999;84(12):4735-8.

18. Wilson RC, Dave-Sharma S, Wei JO, Obeyesekere VR, Li K, Ferrari $P$, et al. A genetic defect resulting in mild low-renin hypertension. Proc Natl Acad Sci USA. 1998;95(17):10200-5.

19. Lavery GG, Ronconi V, Draper N, Rabbitt EH, Lyons V, Chapman KE, et al. Late-onset apparent mineralocorticoid excess caused by novel compound heterozygous mutations in the HSD11B2 gene. Hypertension. 2003;42(2):123-9.

20. Inada M, Iwasaki K, Imai C, Hashimoto S. Two elderly patients with mineralocorticoid excess due to 11 beta-hydroxysteroid dehydrogenase type 2 (11 beta-HSD2) impairment. Intern Med. 2008;47(7):631-6.
21. Nunez BS, Rogerson FM, Mune T, Igarashi Y, Nakagawa Y, Phillipov $\mathrm{G}$, et al. Mutants of 11beta-hydroxysteroid dehydrogenase (11-HSD2) with partial activity: improved correlations between genotype and biochemical phenotype in apparent mineralocorticoid excess. Hypertension. 1999;34(4 Pt 1):638-42.

22. Sambrook J, Fristsch EF, Maniatis TE. In: Molecular Cloning: A Laboratory Manual. Cold Spring Harbor Press, Cold Spring Harbor, NY, USA. 1989.

23. Wilson RC, Harbison MD, Krozowski ZS, Funder JW, Shackleton $\mathrm{CH}$, Hanauske-Abel HM, et al. Several homozygous mutations in the gene for 11 beta-hydroxysteroid dehydrogenase type 2 in patients with apparent mineralocorticoid excess. J Clin Endocrinol Metab. 1995;80(11):3145-50.

24. Ferrari P, Obeyesekere VR, Li K, Wilson RC, New MI, Funder JW, Krozowski ZS. Point mutations abolish 11 beta-hydroxysteroid dehydrogenase type II activity in three families with the congenital syndrome of apparent mineralocorticoid excess. Mol Cell Endocrinol. 1996;119(1):21-4.

25. Wilson RC, Nimkarn S, New MI. Apparent mineralocorticoid excess. Trends Endocrinol Metab. 2001 12(3):104-11.

26. Quinkler M, Bappal B, Draper N, Atterbury AJ, Lavery GG, Walker EA, et al. Molecular basis for the apparent mineralocorticoid excess syndrome in the Oman population. Mol Cell Endocrinol. 2004;217(1-2):143-9.

27. Kamide K, Kokubo Y, Hanada H, Nagura J, Yang J, Takiuchi S, et al. Genetic variations of HSD11B2 in hypertensive patients and in the general population, six rare missense/frameshift mutations. Hypertens Res. 2006;29(4):243-52.

28. Morineau G, Sulmont V, Salomon R, Fiquet-Kempf B, Jeunamaitre X, Nicod J, Ferrari P. Apparent mineralocorticoid excess: report of six new cases and extensive personal experience. J Am Soc Nephrol. 2006;17(11):3176-84.

29. Parra FC, Amado RC, Lambertucci JR, Rocha J, Antunes CM, Pena SD. Color and genomic ancestry in Brazilians. Proc Natl Acad Sci USA. 2003;100(1):177-82.

30. Ollila J, Lappalainen I, Vihinen M. Sequence specificity in CpG mutation hotspots. FEBS Lett. 1996;396(2-3):119-22.

31. el Antri S, Mauffret O, Monnot M, Lescot E, Convert O, Fermandjian S. Structural deviations at $\mathrm{CpG}$ provide a plausible explanation for the high frequency of mutation at this site. Phosphorus nuclear magnetic resonance and circular dichroism studies. J Mol Biol. 1993;230(2):373-8.

32. Rogoff D, Smolenicka Z, Bergadá I, Vallejo G, Barontini M, Heinrich JJ, Ferrari P. The codon 213 of the 11 beta-hydroxysteroid dehydrogenase type 2 gene is a hot spot for mutations in apparent mineralocorticoid excess. J Clin Endocrinol Metab. 1998;83(12):4391-3.

33. Li A, Li KX, Marui S, Krozowski ZS, Batista MC, Whorwood CB, et al. Apparent mineralocorticoid excess in a Brazilian kindred: hypertension in the heterozygote state. J Hypertens. 1997;15(12 Pt 1):1397-402.

\section{Correspondence to:}

Maricilda Palandi de Mello

CBMEG-Unicamp

Caixa Postal 6010

13083-875 Campinas, SP, Brasil

E-mail: mmello@unicamp.br 